\title{
Acquired pure megakaryocytic aplasia successfully treated with cyclosporine
}

\author{
Siklosporin ile başarılı şekilde tedavi edilen kazanılmış saf \\ megakaryositik aplazi
}

\author{
Halima El Omri'1, Firyal Ibrahim², Ruba Yasin Taha1', Riham Hassan Negm¹, Aisha Al Khinji1, \\ Mohammed Yassin'1, Ibrahim Al Hijji1, Hanadi El Ayoubi1', Hussein Baden² \\ 1Department of Laboratory Medicine and Pathology, Al Amal Hospital, Doha, Qatar \\ 2Department of Hematology and Bone Marrow Transplant, Al Amal Hospital, Doha, Qatar
}

\section{A bstract}

Acquired pure megakaryocytic aplasia is a rare hematological disorder characterized by thrombocytopenia with absent or markedly reduced megakaryocytes in the bone marrow. We report a case of a 25-year-old male diagnosed as acquired pure megakaryocytic aplasia. Treatment with prednisone and intravenous immunoglobulin failed, but he was successfully treated with cyclosporine, with complete remission after 90 days and normal platelet count maintained thereafter.

(Turk J Hematol 2010; 27: 289-93)

Key words: Acquired amegakaryocytic thrombocytopenia, steroids, cyclosporine

Received: May 27, 2009

Accepted: J uly 31, 2009

\section{Özet}

K azanılmış saf megakaryositik aplazi, kemik iliğinde namevcut ya da anlamlı ölçüde azaltılmış megakaryosit içeren trombositopeni ile karakterize, nadir hematolojik bir hastalıktır. K azanılmıs saf megakaryositik aplazi teşhisi konmuş, prednizon ve intravenöz immunoglobulin ile tedavisi başarısız olmuş ve siklosporin ile başarılı biçimde tedavi edilerek 90 gün sonra tam remisyona ulaşan ve ondan sonra platelet sayımı normalleşen 25 yaşında erkek bir olgunun raporu sunulmuştur.

(Turk J Hematol 2010; 27: 289-93)

A nahtar kelimeler: Kazanılmış amegakaryositik trombositopeni, steroidler, siklosporin

Geliş tarihi: 27 Mayıs 2009

Kabul tarihi: 31 Temmuz 2009 


\section{Introduction}

Megakaryocytic aplasia, especially acquired pure megakaryocytic aplasia (APMA), is a rare hematologic disorder. APMA is characterized by severe thrombocytopenia resulting from marked decrease or absence of megakaryocytes in the marrow in the presence of otherwise normal erythropoiesis and granulopoiesis. APMA can be either idiopathic or caused by a variety of conditions, such as acquired clonal cytogenetic abnormalities, drug sensitivity, toxin exposure, infectious diseases such as viral infection [1,2], immune diseases such as lupus erythematosus [3], systemic sclerosis [4], eosinophilic fasciitis [5], and malignancy [6,7]. Patients with acquired amegakaryocytic thrombocytopenia may have additional hematological abnormalities such as macrocytosis or dyserythropoiesis, abnormalities which may indicate potential future progression to aplastic anemia or myelodysplasia [8-10].

\section{Case Report}

A 25-year-old male from Nepal presented in August 2008 with a one-week history of headache, gum bleeding and epistaxis. There was no history of trauma, arthralgia, weight loss, drug intake, alcohol consumption, or fever and no family history of bleeding diathesis. He was not known to have any chronic disease. Physical examination showed multiple ecchymoses and petechiae all over the body with bilateral retinal hemorrhage. He had no hepatosplenomegaly or lymphadenopathy.

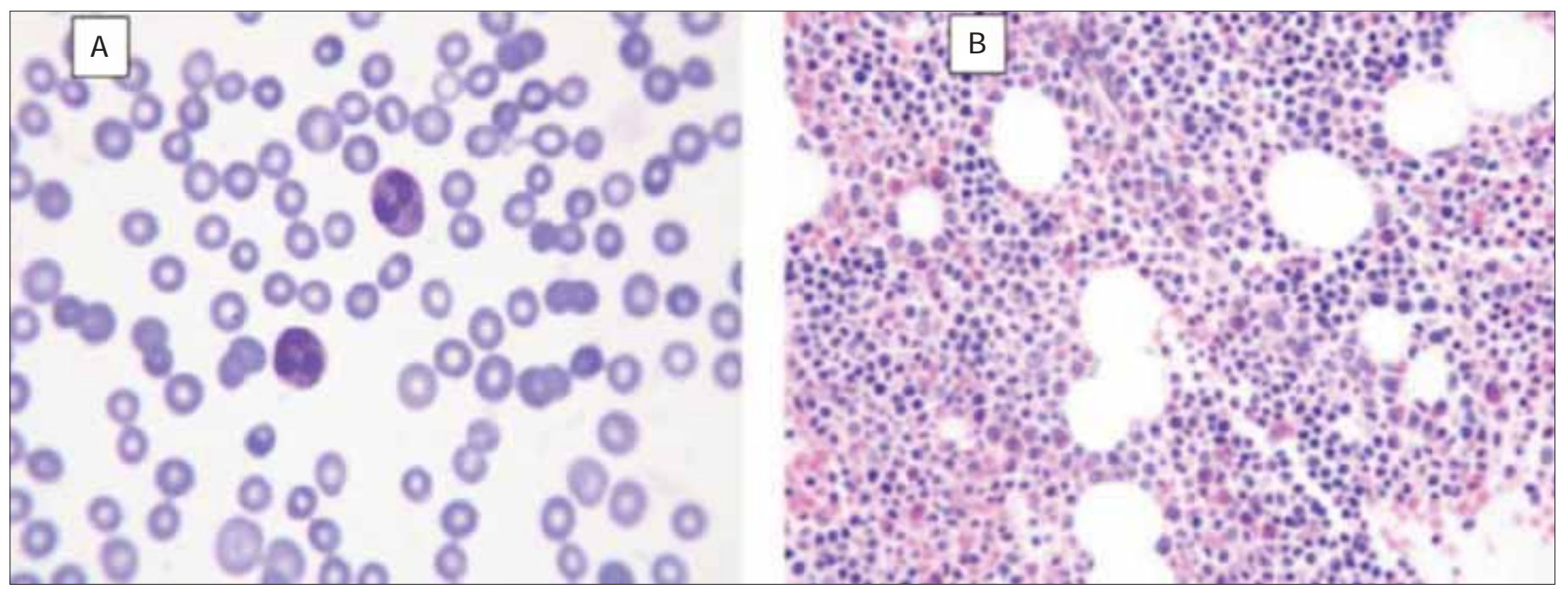

Figure 1. A. Peripheral smear showing severe thrombocytopenia (Wright stain X1000). B: Bone marrow biopsy shows mixed cellular hemopoietic cells with absent megakaryocytes before treatment (H\&E stain X400)
Complete blood count showed white blood cells (WBC) $9.7 \times 109 / \mathrm{L}$ with normal differential, hemoglobin $(\mathrm{Hb}) 9.1 \mathrm{~g} / \mathrm{dl}$, mean corpuscular volume (MCV) $102 \mathrm{fl}$, reticulocytes $7.2 \%$ (total $210 \times 109 / \mathrm{L}$ ), and platelet (PLT) count 5x109/L. Peripheral blood smears revealed normochromic normocytic red cells with polychromasia and markedly decreased PLT. Direct and indirect Coombs tests were negative; prothrombin time, partial thromboplastin time, liver and renal function tests, serum iron, transferrin saturation, serum B12, red cells, and serum folate were all normal. Autoimmune screen including anticardiolipin, antinuclear antibodies, rheumatoid factor, and C3 and C4 were negative. Serological markers for infections like hepatitis virus $(A, B \& C)$ and antibodies against human immunodeficiency virus (HIV), rubella, cytomegalovirus, varicella, herpes simplex virus types $1 \& 2$, Epstein-Barr virus (EBV) and Toxoplasma gondii were all negative; serological test for parvovirus B19 was not done.

The magnetic resonance imaging (MRI) of the brain showed multiple subcentrimetric foci of hemorrhagic lesions in the left and right parietal regions and in the frontal region. Computed tomography scan of the chest, abdomen and pelvis was normal.

Bone marrow aspiration revealed complete absence of megakaryocytes in an otherwise normocellular marrow with active erythro- and granulopoiesis, with no dysplastic features or abnormal cell infiltrates. Iron stores were depleted. The histology of the biopsy and immunohistochemistry using CD61 antibody (GPIIla) confirmed the isolated megakaryocytic aplasia (Figure 1). Cytogenetic analysis of the bone marrow showed a normal male 


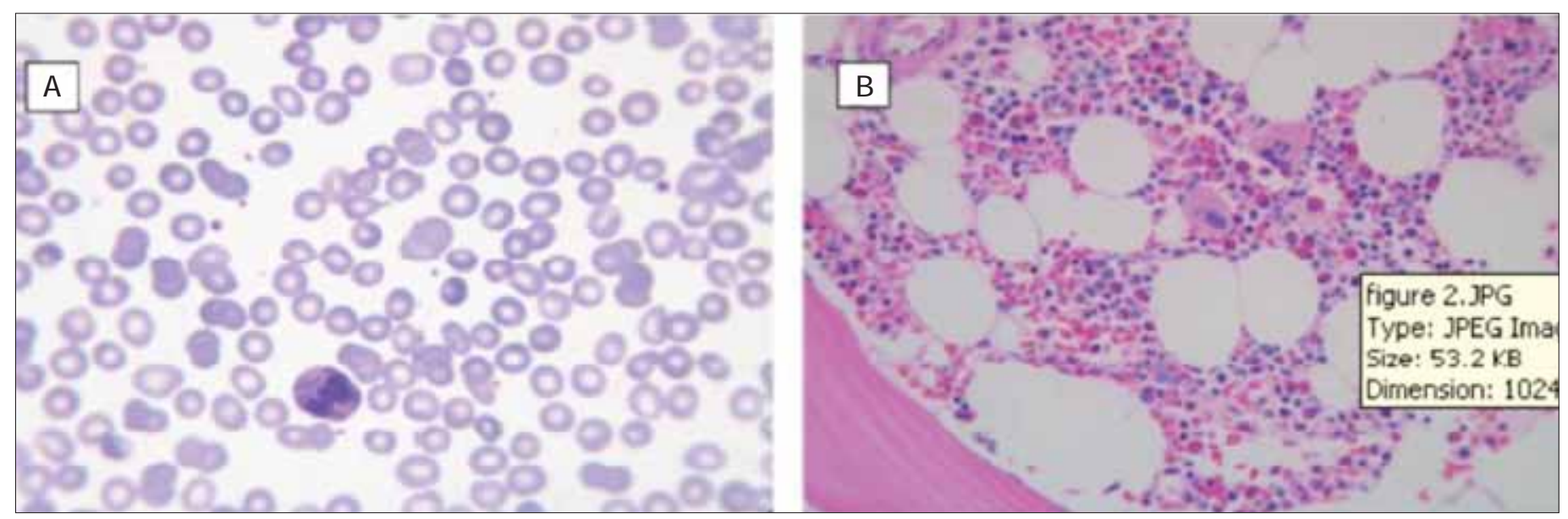

Figure 2. A. Peripheral smear after treatment with cyclosporine (after 3 months) showing normalization of the platelet count (Wright stain X1000). B: Bone marrow biopsy shows active marrow with adequate number of megakaryocytes (H\&E X400)

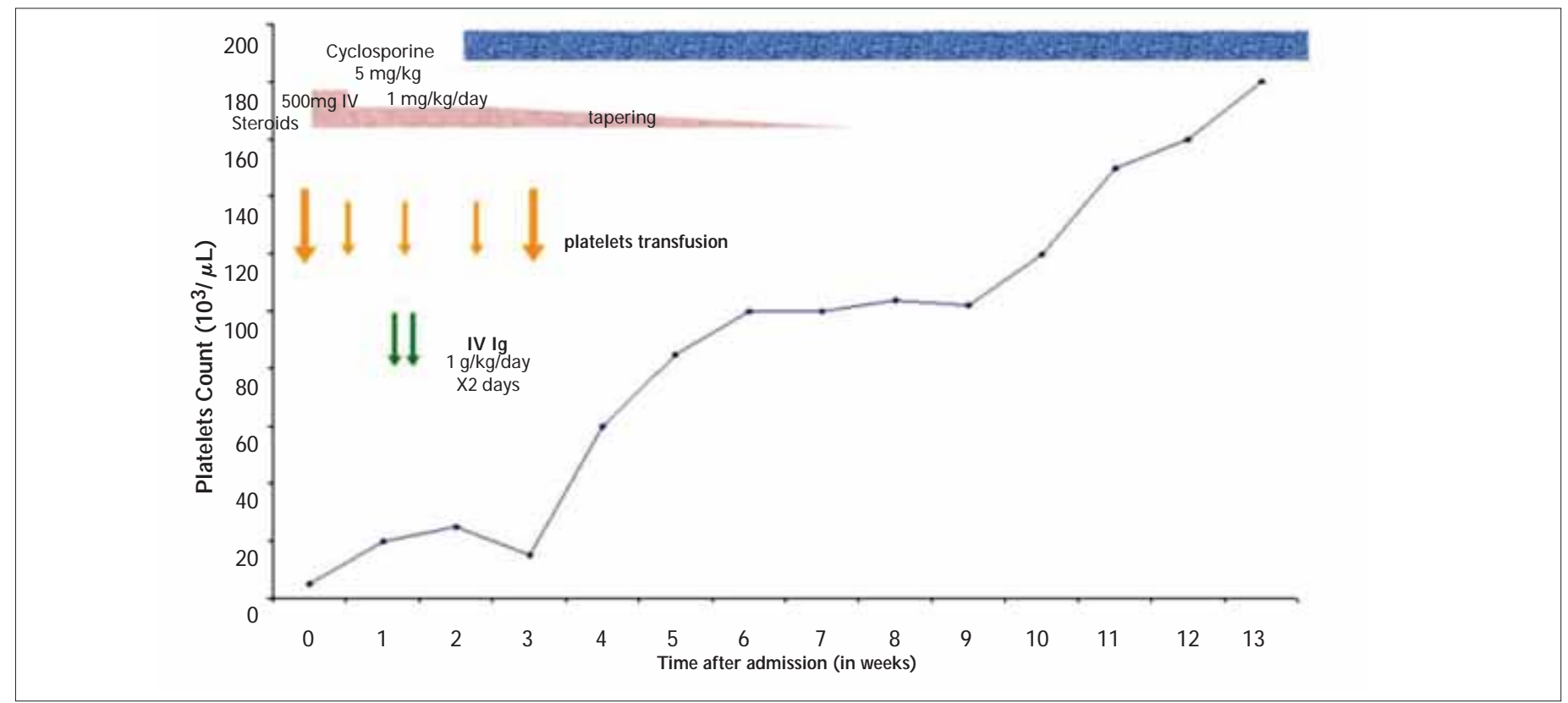

Figure 3. Clinical course with treatment given and changes in platelet count

karyotype. Based on the clinical and laboratory results, a diagnosis of APMA was made.

In view of the widespread hemorrhage and MRI findings, the patient was treated initially with PLT transfusion and methylprednisolone $5 \mathrm{mg} / \mathrm{kg} / \mathrm{day}$ intravenous (IV) for 3 days followed by oral dose of prednisone $1 \mathrm{mg} / \mathrm{kg} /$ day that was continued for 2 weeks and then tapered over 4 weeks until discontinuation. On Day 5 of steroid, no response was obtained, so empirical intravenous immunoglobulin (IVIG) $1 \mathrm{~g} / \mathrm{kg} /$ day for 2 days was added, but again no significant response was achieved. Oral cyclosporine $5 \mathrm{mg} / \mathrm{kg} /$ day was started on Day 12 of treatment, and 2 weeks later the PLT count began to rise and transfusions were no longer required.
The patient was discharged with a PLT count of $60 \times 109 / \mathrm{L}$ and was followed as an outpatient. Three months later, complete blood count normalized, PLT count was $148 \times 109 / \mathrm{L}$ with $\mathrm{Hb}$ of $14 \mathrm{~g} / \mathrm{dl}$, and the bone marrow follow-up was cellular with a good number of megakaryocytes and well-represented erythropoiesis and granulopoiesis (Figure 2). The patient is currently under follow-up with maintenance of a normal PLT count (Figure 3) on the same dose of cyclosporine, with satisfactory therapeutic levels and normal renal function. The plan is to continue cyclosporine for up to one year with gradual tapering of the dose before stopping. Waiver consent is available at Hamad Medical Corporation Research office. 


\section{Discussion}

Isolated thrombocytopenia and megakaryocytic aplasia, inconsistently described as APMA or acquired amegakaryocytic thrombocytopenia purpura (AATP), is a rare disease in the field of hematology. The exact prevalence is unknown and the available literature comprises case reports and small case series. It is possible that the incidence rate is higher than what is reported and that many of the cases are underdiagnosed or misdiagnosed as immune thrombocytopenia [10]. The clinical course of this rare disease seems to be variable. In some patients, it progresses rapidly to aplastic anemia [8] or myelodysplasia [9]. The usual clinical presentation of APMA is with bruising and bleeding with the absence of splenomegaly.

The exact pathogenesis behind this disease is still uncertain; several studies suggest an immunemediated process. Benedetti et al. [11] showed cell-mediated immunosuppression of megakaryocytes by demonstrating a marked increase in T-activated suppressor cells (CD8+/DR+) in association with AATP. A role for humoral immunity was also proposed in the pathogenesis of AATP when Katai et al. [12] showed significant suppression of megakaryocyte colony formation of normal marrow cells with the addition of AATP patient serum to marrow cultures. Antibodies against thrombopoietin have been described to cause this disorder [13], as have antibodies against the TPO receptor, the c-mpl $[3,14]$. Chromium-tagged survival studies in patients with APMA have shown normal results, ruling out PLT destruction or sequestration [15].

Due in part to the heterogeneous nature of the syndrome and the variety of the pathogenic mechanisms, no standard treatment has been established; however, several empirical therapies are used in patients with AATP and include the administration of corticosteroids, IVIG, cyclophosphamide, vincristine, cyclosporine, anti-thymocyte globulin (ATG), splenectomy [15-18], allogenic bone marrow transplantation [19], and recently, mycophenolate mofetil [20].

The administration of corticosteroids, IVIG, cyclophosphamide, vincristine, androgens, and mycophenolate mofetil are transiently effective in occasional patients with AATP $[1,15,16,20]$; however, the administration of cyclosporine alone or in combination with ATG was shown to be very effective in the treatment of AATP $[10,15,17,18]$.
Our patient represents a typical case of APMA with severe thrombocytopenia and absent marrow megakaryocytes. Predictors that indicate the disease progression such as clonal cytogenetic abnormalities, macrocytosis or dyserythropoiesis were not present; the anemia was explained by the significant mucocutaneous bleeding or autoimmune mechanism. No obvious cause of the APMA could be found in this patient. There was no history of exposure to chemicals or drugs, and clinical examination and investigations excluded collagen diseases, infections, malignancies, and congenital anomalies like absent radius. Unfortunately, tests for TPO and c-Mpl antibodies are not available in our center.

The response to immunosuppressive treatments, especially the cyclosporine, would suggest an immune-mediated pathogenetic mechanism. Normalization of the PLT count was achieved 90 days after the start of treatment. As of the preparation of this report, the patient is well, with a PLT count of $198 \times 109 / \mathrm{L}$ and $\mathrm{Hb}$ of $14 \mathrm{~g} / \mathrm{dl}$, maintained on $5 \mathrm{mg} / \mathrm{kg} /$ day cyclosporine (for 7 months from the initiation of treatment), with continuing monitoring to ensure response and to detect any progression to aplastic anemia or myelodysplastic syndrome.

In conclusion, this case report supports the effectiveness of cyclosporine at the prescribed dose of 5 $\mathrm{mg} / \mathrm{kg} / \mathrm{day}$ in the management of APMA.

\section{Conflict of Interest}

No author of this paper has a conflict of interest, including specific financial interests, relationships, and/or affiliations relevant to the subject matter or materials included in this manuscript.

\section{References}

1. Felderbauer P, Ritter PR, Mattern D, Schmitz F, Bulut K, Ansorge N, Schmitt-Graeff A, Schmidt WE, Baier JE. Acquired pure megakaryocytic aplasia: a separate haematological disease entity or a syndrome with multiple causes? Eur J Haematol 2004;72:451-4.

2. Bhattacharyya J, KumarR, Tyagi S, Kishore J, Mahapatra M, Choudhry VP. Human parvovirus B19-induced acquired pure amegakaryocytic thrombocytopenia. $\mathrm{Br}$ J Haematol 2005;128:128-9.

3. Kuwana M, Kaburaki J, Okazaki Y, Miyazaki H, Ikeda Y. Two types of autoantibody-mediated thrombocytopenia in patients with systemic lupus erythematosus. Rheumatology (Oxford) 2006;45:851-4. 
4. Katsumata Y, Suzuki T, Kuwana M, Hattori Y, Akizuki S, Sugiura H, Matsuoka Y. Anti-c-Mpl (thrombopoietin receptor) autoantibody-induced amegakaryocytic thrombocytopenia in a patient with systemic sclerosis. Arthritis Rheum 2003;48:1647-51.

5. Chaudhary UB, Eberwine SF, Hege KM. Acquired amegakaryocytic thrombocytopenia purpura and eosinophilic fasciitis: a long relapsing and remitting course. Am J Hematol 2004;75:146-50.

6. Maslovsky I, Gefel D, Uriev L, Ben Dor D, Lugassy G. Malignant thymoma complicated by amegakaryocytic thrombocytopenic purpura. Eur J Intern Med 2005;16:523-4.

7. Lai DW, Loughran TP J r, Maciejewski JP, Sasu S, Song SX, Epling-Burnette PK, Paquette RL. Acquired amegakaryocytic thrombocytopenia and pure red cell aplasia associated with occult large granular lymphocyte leukemia. Leuk Res 2008;32:823-7.

8. King JA, Elkhalifa MY, Latour LF. Rapid progression of acquired amegakaryocytic thrombocytopenia to aplastic anemia. Southern Med J 1997;90:91-4.

9. Erkurt MA, Kaya E, Baran M, Yitmen E, Snel S, Kuku I, Aydogdu I. Rapid progression of acquired amegakaryocytic thrombocytopenia to myelodysplastic syndrome: case report. Turk J Haematol 2005;22:205-8.

10. Niparuck P, Atichatakarn V, ChuncharuneeS. Successful treatment of acquired amegakaryocytic thrombocytopenic purpura refractory to corticosteroids and intravenous immunoglobulin with antithymocyte globulin and cyclosporin. Int J Hematol 2008;88:223-6.

11. Benedetti F, de Sabata D, Perona G. T suppressor activated lymphocytes (CD8+/DR+) inhibit megakaryocyte progenitor cell differentiation in a case of acquired amegakaryocytic thrombocytopenic purpura. Stem Cells 1994;12):205-13.

12. Katai M, Aizawa T, Ohara N, Hiramatsu K, Hashizume K, Yamada T, Kitano K, Saito H, Shinoda T, Wakata S,
Nakahata T. Acquired amegakaryocytic thrombocytopenic purpura with humoral inhibitory factor for megakaryocyte colony formation. Intern Med 1994;33:147-9.

13. Shiozaki H, Miyawaki S, Kuwaki T, Hagiwara T, Kato T, Miyazaki $\mathrm{H}$. Auto antibodies neutralizing thrombopoietin in a patient with amegakaryocytic thrombocytopenic purpura. Blood 2000;95:2187-8.

14. Kuwana M, Okazaki Y, Kajihara M, Kaburaki J, Miyazaki $\mathrm{H}$, Kawakami Y, Ikeda Y. Autoantibody to c-Mpl (thrombopoietin receptor) in systemic lupus erythematosus. Relationship to thrombocytopenia with megakaryocytic hypoplasia. Arthritis Rheum 2002;46:2148-59.

15. Tristano AG. Acquired amegakaryocytic thrombocytopenic purpura: review of a not very well-defined disorder. Eur J Intern Med 2005;16:477-81.

16. El Omri $H$, Skouri $H$, Kraiem I, Latiri A, Khelif A, Korbi S, Ennabli S. Acquired amegakaryocytic thrombocytopenic purpura treated with intravenous immunoglobulins. Ann Med Intern (Paris) 2000;151:223-6.

17. Quintas-Cardama A. Acquired amegakaryocytic thrombocytopenic purpura successfully treated with limited cyclosporine A therapy. Eur J Haematol 2002;69:185-6.

18. Leach JW, Hussein KK, George JN. Acquired pure megakaryocytic aplasia. Report of two cases with longterm responses to antithymocyte globulin and cyclosporine. Am J Hematol 1999;62:115-7.

19. Lonial S, Bilodeau PA, Langston AA, Lewis C, MossaviSai S, Holden JT, Waller EK. Acquired amegakaryocytic thrombocytopenia treated with allogeneic BMT: a case report and review of the literature [review]. Bone Marrow Transplant 1999;24:1337-41.

20. Bulchandani D, Nachnani J, Belt R, Hinton S. Acquired pure megakaryocytic aplasia: report of a single case treated with mycophenolate mofetil. Am J Hematol 2007;82:650-1. 